\title{
Flow Cytometry: Principles and Instrumentation
}

\author{
Rafael Nunez* \\ Associate Laboratory Member, Memorial Sloan-Kettering \\ Cancer Center, Box 98, 1275 York Avenue, New York, \\ NY 10021, USA
}

\section{Introduction}

The standard benchtop flow cytometer is very similar to a hematology cell counter. In fact, flow cytometers can trace their origins back to the early hematology counters. Unlike their earlier counterparts that used electronic impedance to measure particles in a fluid stream, today's modern flow cytometers use an illuminating light source usually consisting of a laser or arc lamp. The majority of instrument manufacturers employ an air-cooled argon gas laser emitting a monochromatic beam of light fixed at $488 \mathrm{~nm}$ at $15 \mathrm{~mW}$ of power. As particles or cells flow in single file past the intersection of the light beam, light is scattered in various directions. If there a fluorochrome labeled monoclonal antibody associated with the cell, it becomes excited by the laser and a fluorescent emission results. The resulting signals are processed to gather information about the relative size of the cell (forward light scatterFSC), its shape or internal complexity (side light scatterSSC) as well as a diversity of cellular structures and antigens (fluorescence).

The cytometer itself is set up and monitored routinely with a quality control program utilizing a series of unlabeled and fluorescently labeled calibration particles as a reference check on instrument alignment and sensitivity performance. Therefore, every cytometric procedure performed is a reflection of the quality of the instrument, sample preparation, and the operator, and ultimately reflects on the institution.

\section{FACSCalibur $^{\mathrm{TM}}$}

The FACSCalibur uses an air-cooled argon gas laser regulated at $15 \mathrm{~mW}$ of power and a fixed wavelength emission of $488 \mathrm{~nm}$. The instrument is capable of detecting six parameters: Forward Scatter (FSC), side scatter (SSC) and three fluorescent emissions (green, yellow-orange and red) utilizing the first laser. A smaller diode laser emitting red light at $635 \mathrm{~nm}$ is used to excite compounds that fluoresce above $650 \mathrm{~nm}$ and are detected with the fourth fluorescent detector (photomultiplier tube). Figures 1-3 illustrate the general system design and component layout of a flow cytometer. Figure 1 iilustrates the fluidics of a cytometer. Figure 2 shows the optics of a cytometer with two lasers and the capability to detect up to six parameters. Figure 3 demonstrates the process of acquisition and

*For correspondence. Email nunezn@mskcc.org; Tel. (212) 639-6392; Fax. (917) 432-2333. analysis of a sample and the capabilities to save the data on disks as well as to analyze the data and produce printouts and/or slides.

There is a large number of fluorogenic dyes available that can be covalently coupled to antibodies or used for intracellular staining of various cellular constituents. The most widely used fluorochrome for immunophentyping is fluorescein isothyocyanate (FITC) and is detected in the green channel or FL1. Phycoerythrin (PE) emits in the yellow-orange region and is detected in FL2, while Propidium lodide is a DNA specific dye that can be measured in either the orange or red channel (FL2 or FL3). Additional dyes like PerCP, TriColor and Red613 can be excited by $488 \mathrm{~nm}$ and emit in the red wavelengths.

FACSComp ${ }^{\mathrm{TM}}$ software is a software application for automating the setup and electronic compensation necessary when using multiple fluorochromes. FACSComp is used in conjunction with Calibrite ${ }^{\mathrm{TM}}$ beads which are polystyrene beads impregnated with the appropriate fluorochrome. The software informs the user when to insert the required tube, the compensation and sensitivity being performed automatically. Results are displayed on the video monitor, saved by the system, and a printout is available as a record for quality control purposes.

Unlike the traditional benchtop cell analyzer, the FACSCalibur can separate cells into different collection containers based on their physical properties. This process of selection is the basis for cell sorting (see below). When only analyzing cells, samples are consumed and discarded. The instrument is designed with a closed fluid system, thereby making it ideally suited for working with potentially biohazardous samples, i.e., human blood. Working with blood samples must be authorized and the appropriate precautions implemented.

The FACSCalibur can analyze cell suspensions at the rate of several hundred cells per second. Ideally, each sample to be analyzed should contain a cellular concentration of between $10^{5}-1 \times 10^{6}$. Typically, investigators acquire 5,000 to 10,000 cells per sample file; for sperm analysis up to 100,000 cells could be collected. Larger data files have greater storage requirements and generally require storage media such as Magneto-optical (MO) disks. Normally, data are first saved directly to the hard disk of the PowerPC Macintosh computer. After backing up to a $1.44 \mathrm{MB}$ floppy or $230 \mathrm{MB}$ rewritable optical disks, the data can be transferred to a FACS ${ }^{\mathrm{TM}}$ analysis data station. The off-line work station should contain a copy of the CellQuest ${ }^{\mathrm{TM}}$ data analysis software. Moreover, excellent public domain software for the PC (WinMDI ${ }^{\mathrm{TM}}$ ) and commercially available programs such as $\mathrm{FlowJo}^{\mathrm{TM}}$ for the Macintosh are available from sites on the internet.

The FACSCalibur is easy to use, and in our facility, the instrument is operated by the individual researcher who has participated and successfully completed the training course. The facility maintains a schedule sheet for reserving analysis time on a first-come basis. A block of time can be reserved in advance for sample acquisition or data analysis. 


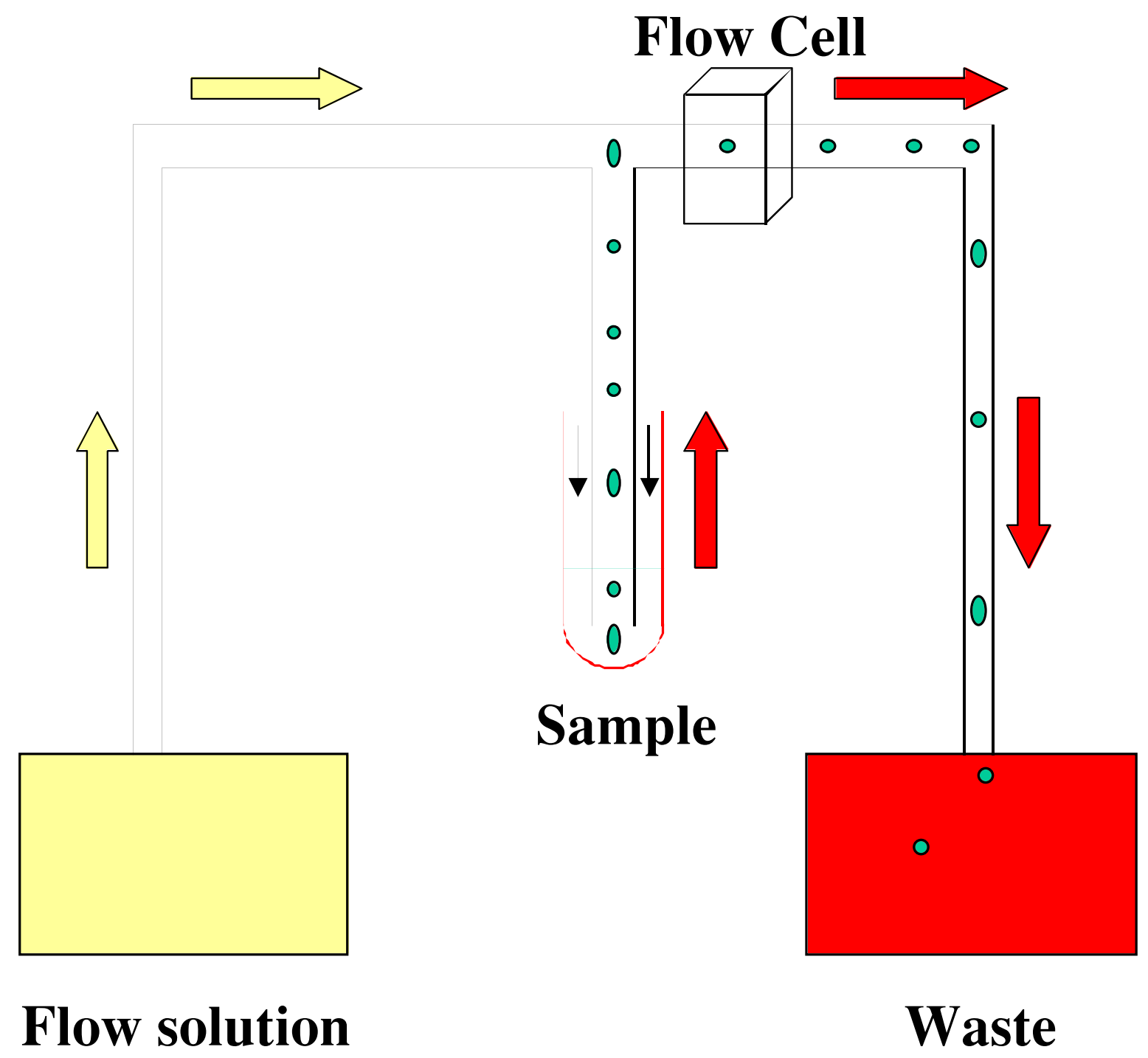

Figure 1. Fluidics. The fluidics of a cytometer.

For additional information on the FACSCalibur instrument, reagents and software, BDIS maintains a web site at: http://www.bdfacs.com/literature/brochures/ Caliburimages/CaliburBro.gif

\section{BD LSR}

The BD LSR ${ }^{\mathrm{TM}}$ is the newest instrument in the flow cytometry line. Introduced in August 1999, this 8 parameter (6 color and two scatter measurements) is a dual laser, benchtop instrument offering simultaneous $488 \mathrm{~nm}$ and UV excitation. It features an air-cooled $8 \mathrm{~mW}, 325 \mathrm{~nm} \mathrm{He}-$ Cd laser in addition to the $15 \mathrm{~mW}, 488 \mathrm{~nm}$ argon-ion laser. Building upon the ease of use of the FACSCalibur, the BD LSR simplifies routine UV applications from the more complex cell sorter instruments to a high performance, compact benchtop flow cytometer. The instrument offers software instrument control, push-button fluidics and fine adjustment sample flow rate control. The optical system is alignment-free and permits the use of UV-excited dyes such as Hoechst 33342, DAPI and Indo-1. Our facility uses the LSR for multicolour analysis (8 parameters).

\section{Characterisitics of a Cell Sorting Instrument and Potential Applications}

A cell sorting instrument is designed first and foremost as a very high-speed sorter and analyzer. It offers the sort performance needed for the quantification and/or isolation of rare cell populations with high recovery and purity. The design specification for a cell sorting instrument includes speeds at or above 25,000 cells per second, and performance approximately 50-100 times faster than existing instruments. Sorted cells must be viable with purity 


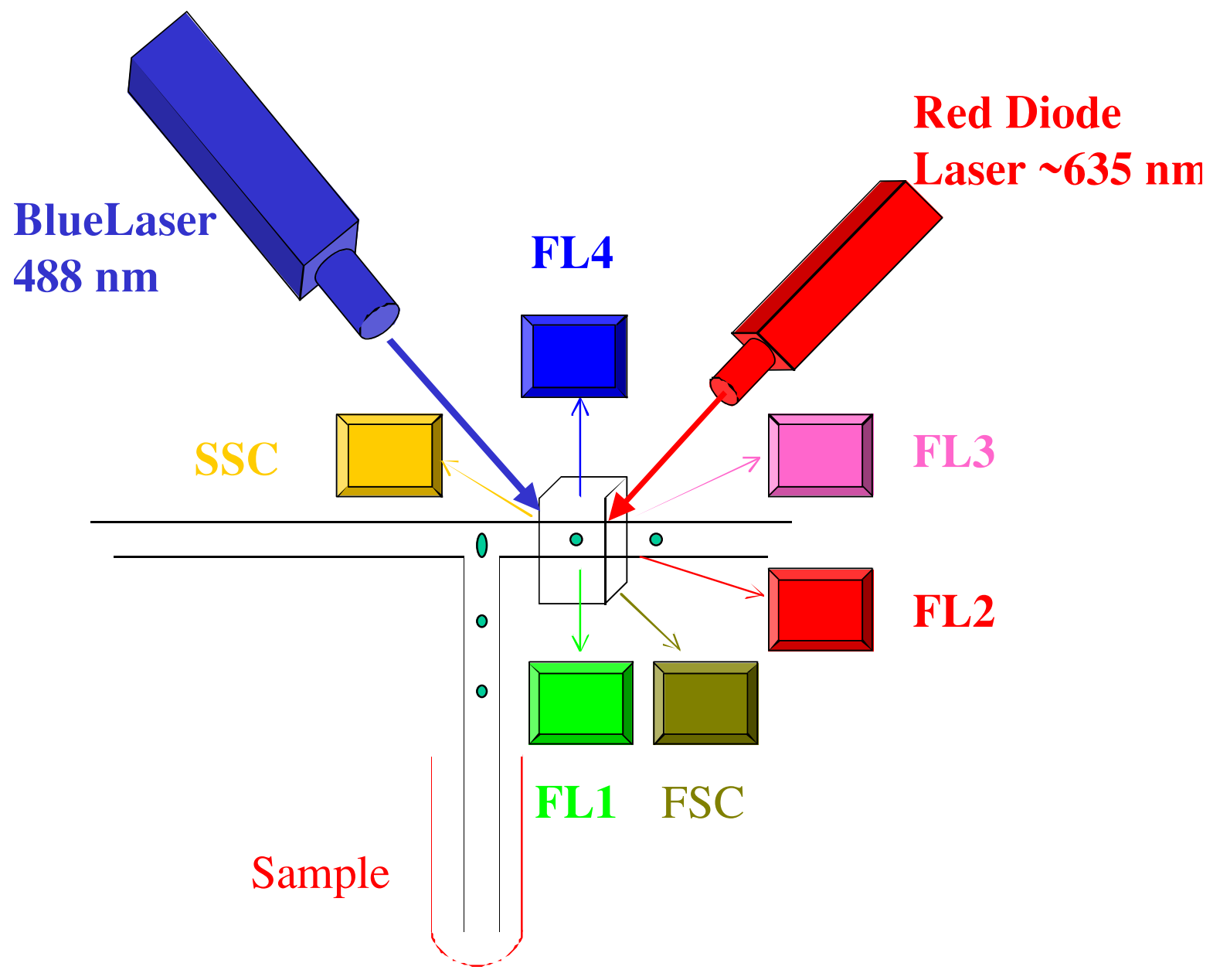

Figure 2. Optics. The optics of a cytometer equipped with two lasers and the detectors for six parameters.

and recovery better than 95 percent at any speed.

Moreover, current performance specifications for a sell sorting instrument include a speed of 50,000 cells per second, with purity and recovery greater than 99 percent at that speed.

A high speed and sensible cell sorting instrument equipped with a single-cell sorting module permits sterile cloning of single cells and allows sorting of single cells directly into tubes for subsequent PCR enzymatic amplification of DNA or RNA from sorted cells. Also online are special home-made, high-resolution time-of-flight sizing systems capable of sizing cells and subcellular organelles as small as 0.3 microns in length or diameter, and a multiparameter high-speed "rare-event" analysis system ("HIGHSPEED") capable of analyzing cells at rates in excess of 100,000 cells per second allowing analysis of rare cell subpopulations as small as 0.0001 percent with sample rates of more than $10^{9}$ cells per hour.

\section{FACSCalibur Sorting Option}

As previously mentioned, the FACSCalibur is equipped with the optional sorting module. The system employs a mechanical catcher tube assembly within the closed fluid system to divert cells to the collection tubes. This method produces no biohazardous aerosols, is ideal for pathogenic samples, but is considerably slower in sorting. For sorting of non-biohazardous samples where the sorting criteria cannot be met on the FACSCalibur, a larger multiparameter jet-in-air cell sorter should be used.

The FACSCalibur can acquire data and sort cells. While acquisition can be performed at rates over 1,000 events per second, the sorting of cells is limited to approximately 300 per second. Non hazardous living cells can be sorted, and may be recovered in gnotobiotic ("sterile") form for subsequent in vitro functional studies.

Although sample acquisition on the FACSCalibur is performed by the researcher, sorting of cells is a more complex procedure requiring precise alignment. Because of its open design, which permits great flexibility in configuration, its delicate components are much more easily damaged by inexperienced operators, and quite expensive to replace. Therefore operation of the FACSCalibur for sorting purposes is restricted to trained operators. 


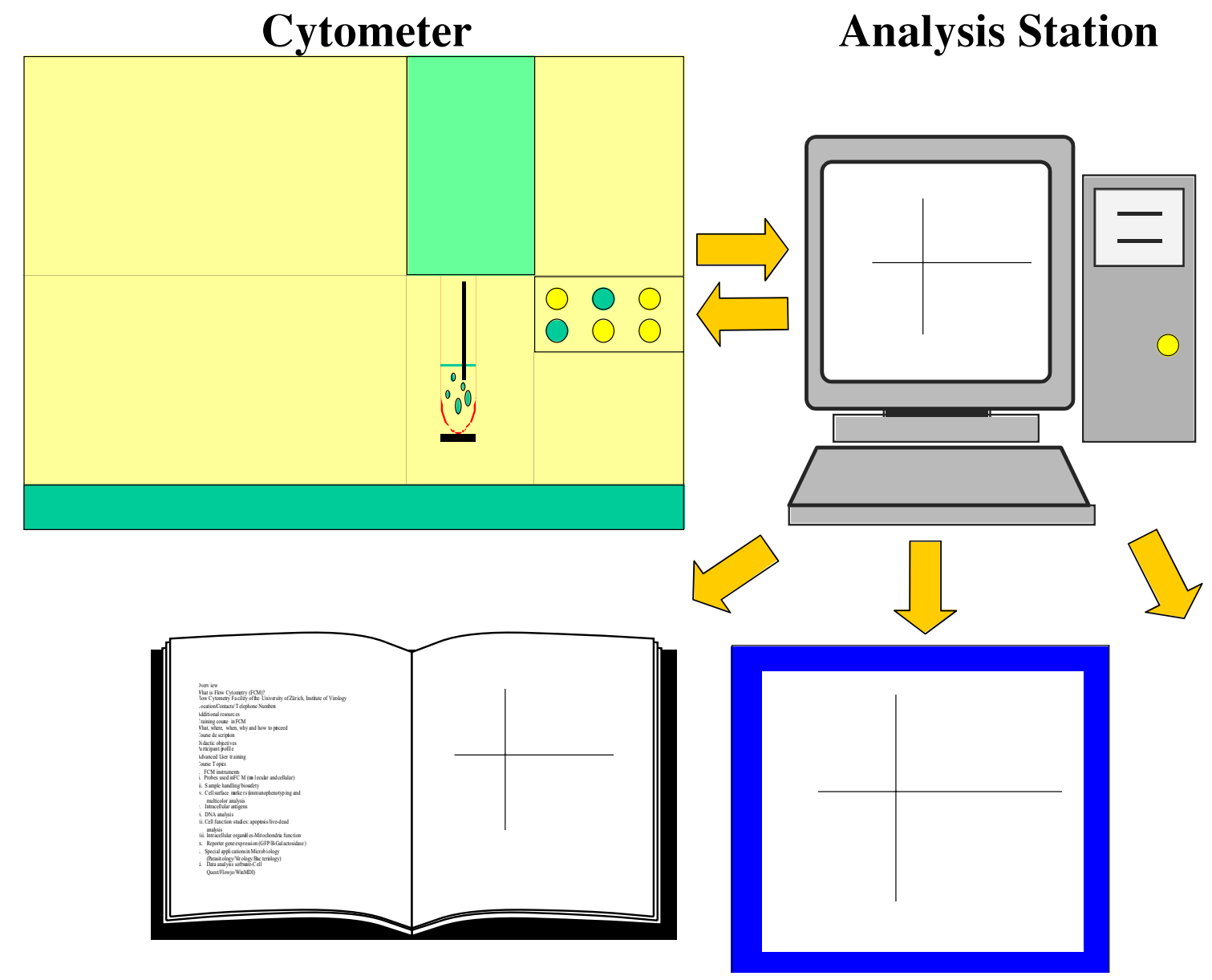

Figure 3. Acquisition and analysis. The process of acquisition and analysis of a sample and the capability to save the data on disks as well as to generate print outs and/or design slides.

\section{FACS Vantage ${ }^{\mathrm{TM}}$ and Vantage SE}

The Becton-Dickinson FACS Vantage Cell Sorter instrument is capable of sorting cells at a much higher speed than the FACSCalibur. Unlike the Calibur which has an enclosed sorting system, the FACS Vantage uses a jetin-air system to achieve greater sort speeds. With robust analytical capabilities and flexibility in changing the optical configuration and adding of lasers, a wider range of fluorochromes can be used for analysis and sorting applications (Figure 4). Digital hardware (DIVA) was incorporated to make the sorter more user-friendly.

\section{Beckman Coulter}

Beckman Coulter manufactures the COULTER ${ }^{\circledR}$ EPICS $^{\circledR}$ XL/XL-MCL FlowCytometry System for bench top operations and the "EPICS ${ }^{\circledR}$ ALTRA $^{\mathrm{TM}}$ and HyPerSort ${ }^{\mathrm{TM}}$ High-Performance Cell Sorting System with capability for high speed sorting applications.

\section{Coulter ${ }^{\circledR}$ EPICS ${ }^{\circledR}$ XL/XL-MCL FlowCytometry System}

The Coulter ${ }^{\circledR}$ EPICS $^{\circledR}$ XL Flow Cytometer combines the analytical power of a research cytometer into a compact, ergonomically designed clinical analyzer. The XL System features the capability to analyze up to four colors of immunofluorescence from a single air cooled laser. Other multi-color applications include: multiparametric DNA analysis, platelet studies, reticulocyte enumeration, cell biology/functional studies as well as a broad range of research applications.

For research applications, the user has the ability to change the optical filters for each fluorescent measurement channel. For high volume users, the XL-MCL System offers walk-away sample handling with the Multi Carousel Loader (MCL). This device incorporates positive bar-code identification and vortex mixing prior to sample aspiration.

The XL uses Digital Signal Processing (DSP) for reliable linearity and drift-free amplification and compensation. Multi-fluorochrome compensation is 


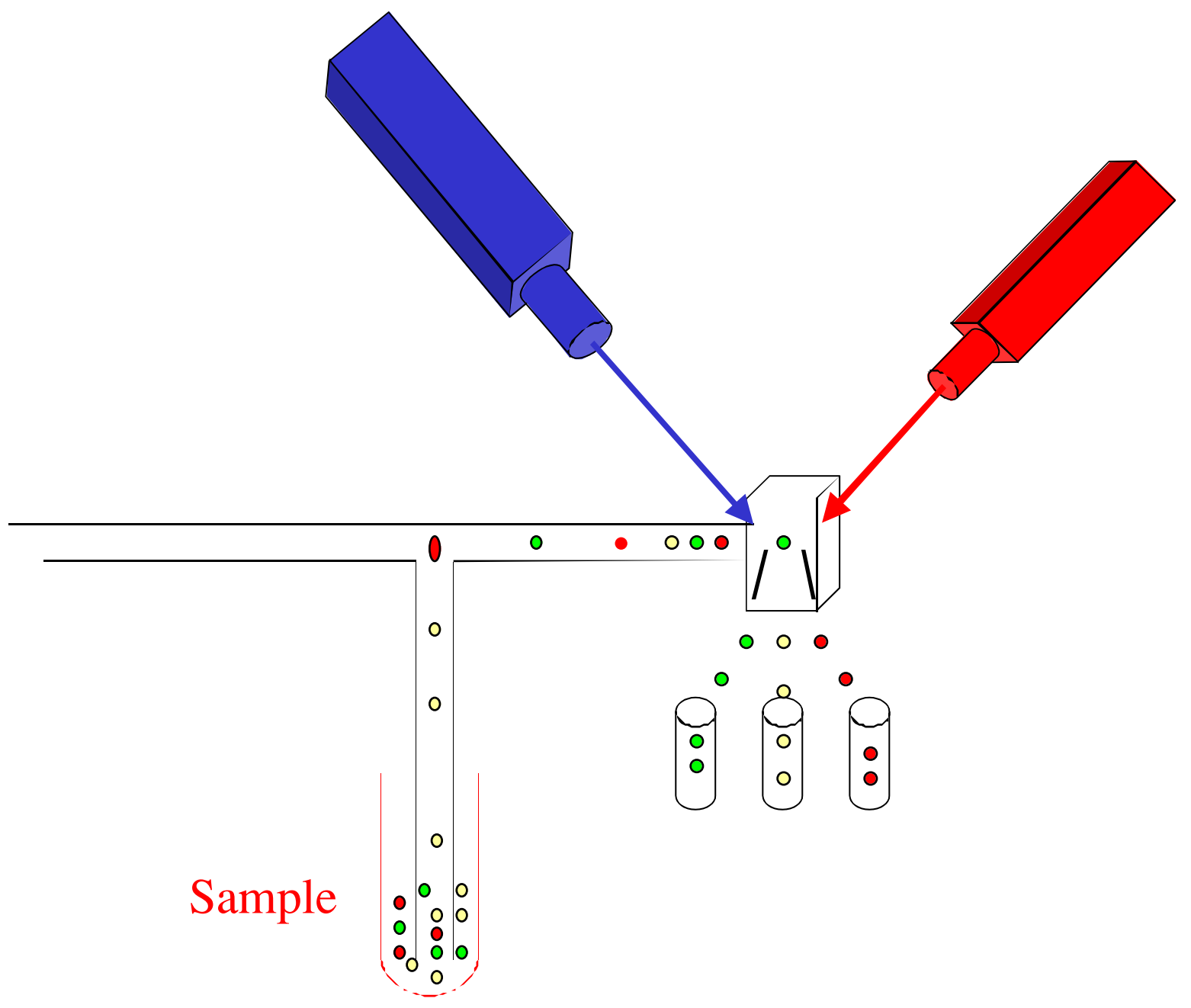

Figure 4. Sorting. This figure illustrates the general system for sorting with a flow cytometer.

achieved by a digital compensation matrix. The new XL SYSTEM II ${ }^{\mathrm{TM}}$ Software fully automates instrument set-up and compensation for 2, 3 and 4-color applications. Optional features in the software include tetraONE, the 4color, one tube, automatic analysis algorithm and reticONE, an analysis algorithm for reticulocyte analysis.

\section{EPICS $^{\circledR}$ ALTRA $^{\mathrm{TM}}$ and HyPerSort ${ }^{\mathrm{TM}}$ High-Performance Cell Sorting System}

The EPICS ALTRA flow cytometer represents a new generation of cell sorters from Beckman Coulter. This highperformance instrument is a powerful tool for innovative research in immunobiology, cell physiology, molecular biology, genetics, microbiology, water quality and plant cell analysis. High fluorescence sensitivity with quartz SortSense ${ }^{\mathrm{TM}}$ flow cell design, for sense-in-quartz, jet-inair operation. The system features the capability to analyze and sort on up to 6 colors simultaneously while performing complex multi-parameter applications. These include DNA cell-cycle analysis, quantification, functional studies, chromosome enumeration and physiological measurements.
The standard ALTRA System allows rapid separation of large numbers of specific cell populations with high purity, recovery and yield. Sorting at rates up to 10,000 cells per second (with air-cooled lasers) and up to 15,000 cells per second (with water-cooled lasers) is possible. The system features eight sort modes. Four modes optimize between purity and yield for two sorted populations, including a special enrichment mode. Three modes feature the new ALTRASort $^{\mathrm{TM}}$ mixed-mode that isolates a high purity population to the left and captures the remainder of the same population to the right. This is ideal when working with rare populations and/or limited sample volume.

The AccuSort ${ }^{\mathrm{TM}}$ mode is for accurate counting when sorting individual cells for cloning with the Autoclone ${ }^{\circledR}$ sorting option or for sort matrix verification. The optional HyPerSort ${ }^{\mathrm{TM}}$ System incorporates new sorting technology that provides true high speed sorting, while maintaining sensitivity with the SortSense flow cell. HyPerSort technology uses high pressure and high frequency to maximize purity, recovery and yield at data rates up to 30,000 cells per second.

This user-configurable optical platform permits choosing from an extensive range of laser options, allowing 
almost any combination of excitation wavelengths. The FlowCentre ${ }^{\mathrm{TM}}$ workstation, a high performance multi-media platform incorporates Intel ${ }^{\circledR}$ Pentium ${ }^{\circledR}$ processing chip technology. The system features EXPOTM Software for instrument control, data acquisition and analysis in a Windows 95 environment.

\section{MoFlo ${ }^{\circledR}$ Cytometers}

Cytomation http://www.cytomation.com/index.htm has developed diverse systems for flow cytometry. The MoFlo ${ }^{\circledR}$ MLS Flow Cytometer is a high-performance cell sorting system for high speed sorting applications. In addition, Cytomation produces a MoFlo ${ }^{\circledR}$ BTA cytometer for bench top analysis, the MoFlo ${ }^{\circledR}$ BTS benchtop sorter and the MoFlo ${ }^{\circledR}$ SX cytometer for $X / Y$ sperm sorting separation.

The MoFlo incorporates parallel processing electronics first developed at the Lawrence Livermore National Laboratory (LLNL) and was used successfully as a chromosome sorter for the Human Genome Project. It was designed first and foremost as a high-speed sorter and analyzer, offering the sort of performance needed for the quantification and/or isolation of rare cell populations with high recovery and purity at speeds in excess of 25,000 cells per second. Current performance specifications claimed by the manufacturer are a sorting speed of 50,000 cells per second, with purity and recovery greater than 99 percent.

Cytomation offers a number of accessories for the MoFlo MLS cell sorter. 4Way ${ }^{\mathrm{TM}}$ Sorting allows researchers to sort up to 4 subsets of cells at one time, using a combination of scatter and fluorescent parameters. This new mode of sorting allows sorting of more subsets faster, and with fewer cells lost to waste.

To ensure accurate cell sorting Cytomation offers Sortmaster $^{\mathrm{TM}}$ an automated system that determines the droplet delay for each sort. The system monitors the droplet break-off during the run, ready to interrupt the sort and determine a new droplet delay if an instability occurs. If a stable break-off point is found, the sort resumes. If not, the sort will be aborted and the operator notified by an audible alarm and/or pager.

CyCLONE ${ }^{\circledR}$ is an automated high-speed cloning device that sorts into trays of 96,384 or 1536 -well configuration. In addition, the software that controls the CyCLONE unit can be configured for any user specified pattern. A 96-well tray can be filled with single cells in under 50 seconds.

\section{Specifications and Characteristics}

Purity, recovery and yield of sorted cells are important parameters that researchers need to be concerned with. The ultimate goal is to obtain the highest values for each of these parameters. In the real world, there is usually a trade-off between these criteria, especially when increasing the sort speed. The MoFlo MLS is capable of generating outstanding purity results such as these at 25,000 events/ second. MoFlo's electronics technology increased speed of sorting without compromising recovery and yield, making the customary problem of turning up the sort speed only to degrade recovery and yield a problem of the past.

One measure of the precision of a cell sorter's performance is the coefficient of variation, simply abbreviated as CV. This is the standard deviation of the mean over the mean. It is a function of how well the optical elements are aligned with the sample stream. When multiple lasers are focused through a single optical element, only one beam can traverse the optical center of the lens. The other beam geometries may be compromised. This situation is best seen by noting the larger CVs generated by the off-axis beam vs. the on-axis beam. The MoFlo eliminates this situation by using separate optical elements for each beam. All beams are spatially separated and optically optimized. New software (Summit ${ }^{\circledR}$ ) improved the analysis capacity of the MoFlo equipment.

\section{The "HiReCS" System Flow Cytometry/Cell Sorting at the University of Texas: A Non-Commercial Flow Cytometer}

The University of Texas has developed diverse technologies in the field of cytometry allowing them to construct their own flow cytometers. The University of Texas facility consists of a home-built, High-Resolution $\underline{\text { Cell }} \underline{\text { Sorter }}$ (the "HiReCS" system) equipped with two lasers. A dual argon-ion laser/dye laser system (a 5 watt UV-enhanced, water-cooled Spectra/Physics Model 2025 argon-ion laser and a $300 \mathrm{~mW}$ air-cooled argon-ion laser (Ion Laser Technology Model 5500AWC) and a Spectra/Physics Model 350 dye head unit which is optically split to provide up to three excitation laser beams at two spatial locations. This configuration provides up to 6-color fluorescence analysis capabilities. Complex 3- and 4-color fluorescence experiments are routinely performed.

Unlike most commercial systems, a home-built computer-controlled 3-color compensation system allows for simultaneous correction of three overlapping fluorescent signals. A single-cell sorting module allows for sterile cloning of individual cells and allows sorting of single cells directly into tubes for subsequent PCR enzymatic amplification of DNA or RNA. A number of other homebuilt, patented devices are incorporated into the system. These include a high-resolution time-of-flight measurement system capable of sizing cells and subcellular organelles as small as 0.3 microns in length or diameter; a multiparameter high-speed "rare-event" analysis system ("HISPEED") capable of analyzing cells at rates in excess of 100,000 cells per second. With this device, analysis of rare cell subpopulations as small as 0.0001 percent with sample rates of more than $10^{9}$ cells per hour can be achieved.

A home-built sophisticated data acquisition system with Windows $^{\mathrm{TM}}$ graphical user interface runs on a $66 \mathrm{MHz}$ 80486 computer and allows for acquisition of 8-parameter, 12-bit listmode data first into RAM, then onto a 200 megabyte disk at rates in excess of 10,000 cells per second. The advanced and unique HiReCS also permits visualization, analysis, and sorting of cells from very complex multi-color fluorescence experiments. Correlation between multiple flow cytometric parameters can be explored through the use of multidimensional principal component/biplot analyses and associated real-time sorting. These analysis and sorting methods can also be used to reduce false-positives. A unique expert system has been developed providing "flexible sorting" strategies to 
optimize sample yield or purity. Instrumentation is continually designed or updated in response to particular biological applications.

\section{Partec $^{\mathrm{TM}}$ Flow Cytometers (CyFlow ${ }^{\circledR}$ and PAS ${ }^{\circledR}$ )}

Partec (http://www.partec.de) has develop the CyFlow ${ }^{\circledR}$, a compact flow cytometer for diverse flow cytometry analysis including the capability to determine absolute volumetric counting. The CyFlow allows to analyze FSC, SSC and up to three fluorescent signals. Since the FloMax ${ }^{\circledR}$ software is PC based, the data acquisition, analysis, and real-time display is performed with any type of PC or laptop within a windows platform. The software allows postacquisition compensation, a very important feature during the analysis.

PAS $^{\circledR}$ is a more sophisticated Compact Flow Cytometer from Partec and it is designed for Multiparameter Flow Cytometry analysis for applications in Immunology,, Microbiology, Biology, Pathology, Hematology including Lymphocyte Subset and Cell biology Analysis

Equipped with an Argon ion laser (488 $\mathrm{nm}$ ) and an HBO lamp for UV excitation it can determine up to 8 parameters: FSC, SSC, FL1 to FL6 (FITC, PI, DAPI, SR, TR, PE-CY5, AMCA, APC, and many more colors and combinations)

It can detected less than 100 FITC molecules, and determine the true volumetric absolute counting that is very useful for assess CD $34+, C D 4 / C D 8$ and other immunolabelled cells without need for reference particles.

The Partec flow cytometers are very robust and compact as well as easy to handle and less demanding in location space, maintenance and service. In addition, the fact that some Partec flow cytometers like the CyFlow ${ }^{\circledR}$ runs on $12 \mathrm{~V}$ DC power (e.g. on a car battery) can be important for users in remote places or in field research and for developing countries. 


\section{Further Reading}

Caister Academic Press is a leading academic publisher of advanced texts in microbiology, molecular biology and medical research. Full details of all our publications at caister.com

- MALDI-TOF Mass Spectrometry in Microbiology Edited by: M Kostrzewa, S Schubert (2016) www.caister.com/malditof

- Aspergillus and Penicillium in the Post-genomic Era Edited by: RP Vries, IB Gelber, MR Andersen (2016) www.caister.com/aspergillus2

- The Bacteriocins: Current Knowledge and Future Prospects Edited by: RL Dorit, SM Roy, MA Riley (2016)

www.caister.com/bacteriocins

- Omics in Plant Disease Resistance Edited by: V Bhadauria (2016) www.caister.com/opd

- Acidophiles: Life in Extremely Acidic Environments Edited by: R Quatrini, DB Johnson (2016) www.caister.com/acidophiles

- Climate Change and Microbial Ecology: Current Research and Future Trend

Edited by: J Marxsen (2016)

www.caister.com/climate

- Biofilms in Bioremediation: Current Research and Emerging Technologies

Edited by: G Lear (2016)

www.caister.com/biorem

- Microalgae: Current Research and Applications Edited by: MN Tsaloglou (2016) www.caister.com/microalgae

- Gas Plasma Sterilization in Microbiology: Theory, Applications, Pitfalls and New Perspectives Edited by: H Shintani, A Sakudo (2016) www.caister.com/gasplasma

- Virus Evolution: Current Research and Future Directions Edited by: SC Weaver, M Denison, M Roossinck, et al. (2016) www.caister.com/virusevol

- Arboviruses: Molecular Biology, Evolution and Control Edited by: N Vasilakis, DJ Gubler (2016) www.caister.com/arbo

- Shigella: Molecular and Cellular Biology Edited by: WD Picking, WL Picking (2016) www.caister.com/shigella

-Aquatic Biofilms: Ecology, Water Quality and Wastewater Treatment

Edited by: AM Romaní, H Guasch, MD Balaguer (2016)

www.caister.com/aquaticbiofilms

- Alphaviruses: Current Biology

Edited by: S Mahalingam, L Herrero, B Herring (2016)

www.caister.com/alpha

- Thermophilic Microorganisms

Edited by: F Li (2015)

www.caister.com/thermophile
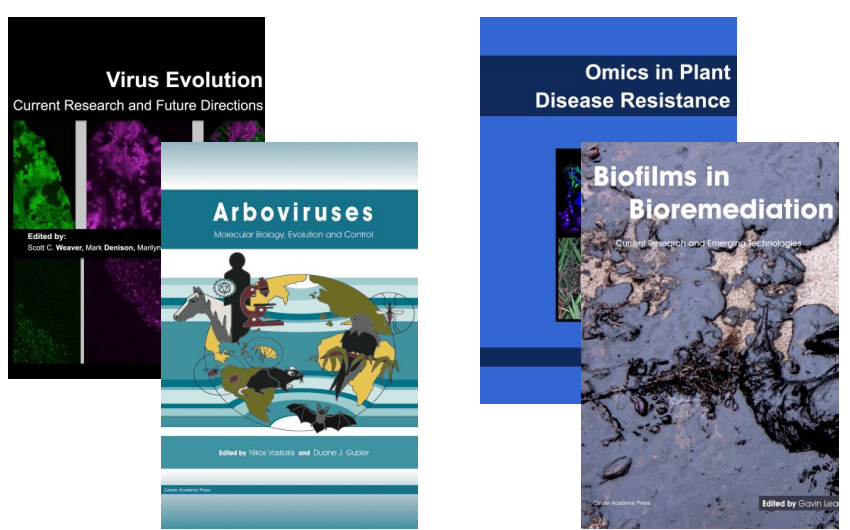
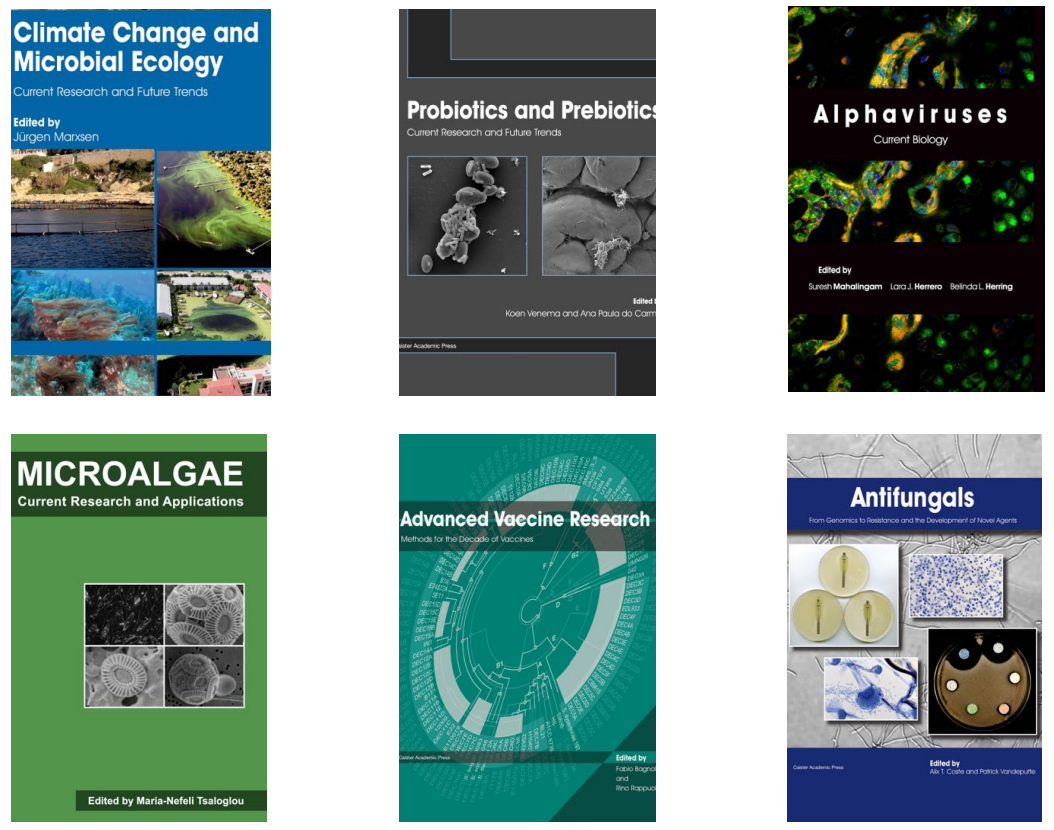

- Flow Cytometry in Microbiology: Technology and Applications Edited by: MG Wilkinson (2015) www.caister.com/flow

- Probiotics and Prebiotics: Current Research and Future Trends Edited by: K Venema, AP Carmo (2015) www.caister.com/probiotics

- Epigenetics: Current Research and Emerging Trends Edited by: BP Chadwick (2015) www.caister.com/epigenetics2015

- Corynebacterium glutamicum: From Systems Biology to Biotechnological Applications

Edited by: A Burkovski (2015)

www.caister.com/cory2

- Advanced Vaccine Research Methods for the Decade of Vaccines

Edited by: F Bagnoli, R Rappuoli (2015)

www.caister.com/vaccines

- Antifungals: From Genomics to Resistance and the Development of Novel Agents

Edited by: AT Coste, P Vandeputte (2015)

www.caister.com/antifungals

- Bacteria-Plant Interactions: Advanced Research and Future Trends Edited by: J Murillo, BA Vinatzer, RW Jackson, et al. (2015) www.caister.com/bacteria-plant

\section{- Aeromonas}

Edited by: J Graf (2015)

www.caister.com/aeromonas

- Antibiotics: Current Innovations and Future Trends

Edited by: S Sánchez, AL Demain (2015)

www.caister.com/antibiotics

- Leishmania: Current Biology and Contro Edited by: S Adak, R Datta (2015) www.caister.com/leish2

- Acanthamoeba: Biology and Pathogenesis (2nd edition) Author: NA Khan (2015)

www.caister.com/acanthamoeba2

- Microarrays: Current Technology, Innovations and Applications Edited by: Z He (2014)

www.caister.com/microarrays2

- Metagenomics of the Microbial Nitrogen Cycle: Theory, Methods and Applications

Edited by: D Marco (2014)

www.caister.com/n2 